\title{
The Colonization of Significance and the Future of the Nation: Fanon, Derrida, and Democracy-to-Come
}

\author{
SHANNON HofF
}

One of the ways to identify the difficulties that confront persons who are queer, not white, not Western, not male, and in multiple other ways different from modes of identification that have designed and achieved the status of "normal," is that they participate less actively in constructing the significance of their own identities than do those normal others. Because this significance is largely a result of the agency of others - that is, because someone else establishes the meaning of such identities and also the way such persons fit into reality - this significance can be called colonized. Such colonization is a powerful interpretive gesture involving the projection of an identity for an entire group of people, a projection encompassing the past of that identity - the process of its formation - as well as its future possibilities. In thus establishing the terms of past and future, this interpretive gesture renders both the identity and the resistance of the colonized consciousness always already appropriated: both alternatives - to assume the role assigned to it by the dominant group or culture, or to oppose it inverting the hierarchy and celebrating those characteristics of identity that are devalued by the dominant group or cultureare tethered to this powerful interpretive gesture inasmuch as that interpretation is still setting the terms for understanding the reality of the non-dominant group. This control by the dominant group of both options - acceptance and refusal—is the troubling bind of colonization. ${ }^{1}$ 
This problem is a persistent one, but it is one for which Frantz Fanon's attempt to deal with the dilemma of colonized consciousness in the context of Algerian decolonization offers a uniquely powerful solution. Fanon's challenge is to identify the possibility of agency and resistance for a colonized subject, whose agency has been shaped and organized by others in certain ways, and whose resistance is appropriated by the system being resisted in that it is always already determined by it. Fanon's solution is a national consciousness of a particular kind, aided by violence, but a national consciousness that would prepare the ground for a new kind of humanity and internationalism - that Europe, he says, could not create. It is a "national consciousness" that would be "capable of giving us an international dimension," a "national liberation" that would put "the nation on the stage of history," which is a shared stage (Wretched 179-80, Damnés 235).

In Rogues, Jacques Derrida explores a tension that is similar to the one in Fanon's writing between nationalism and internationalism, and that, I will argue, provides a new answer to the question of how to reconcile Fanon's international, humanist hope with his national consciousness and advocacy of divisive violence. This tension is located, for Derrida, between particularity and particular democracies, on the one hand, and, on the other, something like the internal impetus in the concept of democracy to universality and universal concern, or (and Derrida struggles to name it) "democracy to come," "the concept to come of democracy," "what democracy is," which is "a meaning in waiting, still empty or vacant" (Rogues 8-9). Derrida suggests that a de-limited, particular, sovereign democracy, which is essentially closed off to its others, is alone capable of responding to the demand of democracy for democracy - a demand that propels such a particular democracy beyond the de-limited borders of its own sovereignty, beyond its own restricted attempts to answer its own demands. Democracy exists only in the 
negotiation of the tension between the one truth of the democratic-sovereignty, selfdetermination, majoritarian rule, and the other truth-or, that is, the truth of the other, of heterogeneity, the weak, the suffering, the excluded, the anyone (Rogues 14). In bringing this tension that Derrida discovers at the heart of democracy to bear on the tension in Fanon's work between the nation and the impetus to internationalism, I will argue that such ambivalence or tension is necessary to political, democratic self-determination; democracy only exists as an irresolvable tension between the determinacy of decision and the indeterminacy required by democratic hospitality to what may make itself known.

I will begin by specifying what Fanon should be taken to mean by national consciousness, and what purpose the existence of national consciousness has. This will require me to explain, in the first section, the colonial production of the significance of the colonized subject to which national consciousness is invoked as a response, and, in the second, the precise way in which Fanon defines and defends national consciousness as the appropriate response to this production of significance. I will then investigate, in the third section, how and why the universal ideals of Western political contexts fail to operate as ideal in the colonial context, and, how from this failure, and with Fanon's alternative vision of universality, we can learn how to reorient our legal and political vision. In the fourth section I will explore Derrida's account of democracy and the ambivalence between exclusion and inclusion, nationalism and internationalism, exploring the rich similarities between Fanon and Derrida, and showing how Derrida's work is a powerful resource for the development of Fanon's critique of colonialism and strategies for decolonization. My goal is to illuminate and link various ideas in Fanon's thinking in order to bring it to bear on the issue of the contested status of universal principles in relation to justice, and in order to enable further reflection on the significance of national 
consciousness in a global political context that is suspicious of it. More specifically, I will argue that we can take from Fanon the following idea: the reconstitution of agency in the wake of colonialism requires a national consciousness, but, although this national consciousness rejects the universality presented by the political terms of the West, it offers an image of a different kind of universality, one helpfully articulated in the terms that Derrida uses to explain democracy.

\section{The colonial production of significance}

Let us begin by exploring the problem of what kind of agency is available for one whose identity is interpreted and shaped by others, showing how in Fanon's powerful explication of the experience of being black and colonized is found a sophisticated account of agency in the context of restriction. Fanon begins the pivotal chapter of Black Skin, White Masks, "The Lived Experience of the Black Man," by narrating his slow discovery of the way in which every piece of him and every account he gives of himself has already been captured and construed by the system of significance of the "white man" and of colonization. ${ }^{2}$ Everywhere he turns, and in everything he does, he runs into a white explanation of his behaviour and a white interpretation of reality and his place in it. When subjected to "an objective gaze," Fanon writes, I "discovered my blackness, my ethnic features; deafened by cannibalism, backwardness, fetishism, racial stigmas, slave traders, and above all, yes, above all, the grinning $Y$ a bon Banania" (Black Skin 92, Peau Noire 90). ${ }^{3}$ Dismembered by colonization, the black man's fragments are "put together by another," an other self, a white self (Black Skin 89, Peau Noire 88). The black man is composed as a self and a body by the white man: "The data I used were provided ... by the Other, the white man, who had woven me out of a thousand details, anecdotes, and stories" (Black Skin 91, Peau Noire 90). ${ }^{4}$ 
In order, then, to participate in meaning, interpretation, and action, the black man must turn to the only script that is left to him - the script produced by the white world. However, since this schema is premised on the assumption that black subjects do not make their own sense or meaning, the black man is defined as incapable of adopting it; he cannot attempt to be an agent in a system that defines him as a non-agent (Black Skin 94, Peau Noire 92). The white world ties agency and responsibility to individuals, and then refuses to recognize the "black man" or colonized subject as an individual. ${ }^{5}$

In an even more powerful gesture, the black man's desire - a matter of his becoming and his future - is also colonized, according to Fanon. The white man is the black man's future; "white" is who he wants to be; "white" represents everything there is that is worthwhile in the world, or that the world recognizes as worthwhile. In The Wretched of the Earth, Fanon remarks that

the gaze that the colonized subject casts at the colonist's sector is a look of lust, a look of envy. Dreams of possession. Every type of possession: of sitting at the colonist's table and sleeping in his bed, preferably with his wife. The colonized man is an envious man. The colonist is aware of this as he catches the furtive glance, and constantly on his guard, realizes bitterly that: "They want to take our place." And it's true that there is not one colonized subject who at least once a day does not dream of taking the place of the colonist. (Wretched 5, Damnés 43)

Even the colonized subject's aspiration and orientation to the future and to the possibility of transformation are captured and diverted by the phenomenon of colonization. Further, the goods that are presented as desirable are the result of the exploitation of him; they are the goods he produces under the yoke of colonialist exploitation. Thus the black man finds himself in a bind, desiring for himself the products of the very system that relies on exploiting him. His desirebe like the colonist and have what the colonist has-amounts to a kind of acquiescence to and agency in his own subordination. 
According to Fanon, this colonization of desire, the so to speak "psychic fallout" of colonization, can be resolved only by means of the severance of the link between white, Western, and capitalist, on the one hand, and all that is desirable, on the other. To sever this link, the white world must be removed, says Fanon. The terms set by the colonizing power have proven incapable of helping the colonized subject work through his particular desire and complexes, and gain resources for the (re-)construction of significance, since these terms were directly employed in the exploitation of this subject.

What must take the place of the white world is an alternative framework of significance, a physically and politically independent environment that resists discursive engagement with colonial power, that in so doing reappropriates and reconstructs space for psychic development, and that takes on the project of decolonization as a social and collective one. What must develop is a national consciousness that will help this subject free himself from the complexes created by the colonial environment, from the suffocating reality of being made a player in an already existent system, from having his agency and significance defined from the outside.

Fanon's desire, therefore, is that the colonized subject refuses the principles and mechanisms offered and spread by Western colonial powers, to be oriented instead by the local and determinate circumstances shaped by those powers. In order to foster free, flourishing, and democratic subjects whose cooperation in political self-determination is valued, the colonized subject must refuse to engage the rest of the world, to participate in a global universality. For the sake of inclusiveness and responsiveness, that is, it must first be exclusive - it must be a nation, a national consciousness. Let us now turn to a more detailed discussion of Fanon's national consciousness, and his refusal of a certain kind of universality. 


\section{National consciousness}

Fanon argues that the project of decolonization in Algeria requires national consciousness and a national culture. The national consciousness he attempts to describe and mobilize, however, is of a very particular kind, not to be confused with a nationalism that takes its lead from racial, regional, or religious identity - that is, from an identity that is taken to be already comprehensively defined and to be attached to a particular past or narrative. In this section I will discuss what the nation is, what we should understand by national consciousness, why Fanon employs this term and not nationalism, and what characteristics his understanding of national consciousness has.

This national consciousness has four central aspects: 1) the nation is not original but produced through colonization; 2) national consciousness cannot be defined prior to its emergence in the process of active struggle against the colonizer; 3) national consciousness is effective against Western power in that by virtue of its specificity it challenges the increasing homogeneity of global capitalism; and 4) the emergence of national consciousness requires the violent eradication of the entire colonial system.

First, the nation is not original; the group that becomes a nation is defined as such by a socioeconomic system run at its expense. Its identity is produced through the experience of colonization. ${ }^{6}$ European colonialism involved the importation of various kinds of non-indigenous technology, political and police rule, systems of communication, forms of cultural expression and social organization, etc., which entailed the production of new forms of self-consciousness and new perceptions of the significance of human activities and human beings. Fanon, in turn, is not arguing on behalf of a national political entity or national feeling that has its source in the past and a static identity and that encourages arbitrarily exclusive attitudes towards other static 
national forms; he is not glorifying, for instance, a pseudo-mythical origin in shared characteristics such as race or religion, the heritage of which must be jealously guarded. On Fanon's account a colonized people was produced by the colonial context, and to rise up in the form of a nation would be to acknowledge the fact of this situation and identify it as a production. It is to become conscious of, and active on behalf of, the subordinated subjects the colonizing powers have created; it is for these subjects to establish the conditions under which they can produce their own significance. Fanon's nation is the site of its citizens' cultural, social, economic, and political development, which is a matter of the future, and of the dynamism of possibility—not a matter of the celebration of a glorious past. ${ }^{7}$ In sum, the first aspect of Fanon's nationalism is that the nation around which it is mobilized is not original but produced, and that the way to appropriate this productive power is to self-consciously take up such appropriation as a project.

Second, Fanon says that national consciousness and culture will only emerge and be given shape through struggle against the colonizer, or through the exercise, and indeed discovery, of an agency of resistance. In "This is the Voice of Algeria," Fanon observes fragmented acts, ideas, and pieces of reality congealing through struggle into an organized and real identity:

The fragments and splinters of acts gleaned by the correspondent of a newspaper more or less attached to the colonial domination, or communicated by the opposing military authorities, lost their anarchic character and became organized into a national and Algerian political idea, assuming their place in an overall strategy of the reconquest of the people's sovereignty. The scattered acts fitted into a vast epic ... (A Dying Colonialism 84)

The nation of this national consciousness does not yet have an identity delineated on its own terms, precisely because it is brought into existence through oppression and carries the stigma 
and injury of this oppression in its stilted agency. Only in eliminating the system of significance that brought it into being can it come to perceive itself as capable of independence, of elaborating and ascertaining values (Wretched 40, Damnés 79). To define the nation through the exercise of an agency of resistance, through acts in which one finds oneself to be powerful even in opposition to that force that has defined one's power, is the most effective way, in this context, to define and shape an independent identity as a nation. ${ }^{8}$

The shape of this national consciousness cannot be defined and delineated prior to that struggle, according to Fanon, because the identity attributed to it by the colonizer is an inferior and invalid identity, and the identity available to it in the imagined past, prior to colonization, is no longer purely accessible on its own terms, independently of the signifying mediation of the colonizing power. ${ }^{9}$ The discourse of colonization colonizes also the past, turning the past nation into a nation that was destined for failure and reliant on the colonizing people for its salvation, while to attempt a complete return to the past would be to mistakenly presume that the mediation of colonization had no real impact on the way the nation is imagined. The task of the colonized subject is, as Fanon writes, "to put an end to the history of colonization ... in order to bring to life the history of the nation, the history of decolonization" (Wretched 15, Damnés 53)-that is, to bring to life a new history. The new nation must produce also a new past, created and reremembered as the possibility of a different future. What can now be asserted about this new nation is that it is fundamentally different from the world of the colonizer (Wretched 6, Damnés 44), but what it will be, will only be discovered through its creation. As Sartre writes in the preface to The Wretched of the Earth, "the true culture is the revolution, meaning it is forged while the iron is hot" (Wretched xlvii, Damnés 21). ${ }^{10}$ 
The third aspect of national consciousness is the demand that it oppose the particular political and economic shape that colonization has taken: the shape of global Western capitalism. If the system that continues to perpetuate the subordination of nations that are in the process of de-colonizing is the political economy of European capitalism that ignores national borders and human self-determination in the name of the flow of capital and surplus value, then resistance to it requires the assertion of national borders in the name of self-determination and human value. The task for this nation, for Fanon, is to take itself out of this global, homogenized economy that has created it as an irreversibly subordinate player.

In this vein, Fanon challenges the bourgeois business and intellectual elite of the native population whom he accuses of adopting the Western mantle, taking over the positions of power, and making themselves instruments of Western capital (Wretched 99, Damnés 146) in the spirit of "neo-colonialism" (Wretched 101, Damnés 149). He writes, "for the [national] bourgeoisie, nationalism signifies very precisely the transfer into indigenous hands of privileges inherited from the colonial period" (Wretched 100, Damnés 148), and he attributes the "virtually endemic weakness of the underdeveloped countries' national consciousness" not just to "the colonized subject's mutilation by the colonial regime" but also "to the apathy of the national bourgeoisie, its mediocrity, and its deeply cosmopolitan mentality" (Wretched 98, Damnés 146). With his critique of this cosmopolitan mentality, we see a suggestion of that internationalism or universalism from which he will distinguish his own, a distinction to which I will turn in the next section.

The fourth characteristic to note about Fanon's particular vision of nationhood, and the one that has probably inspired the most controversy, is that the creation of the new nation requires violence, or, as he writes in Toward the African Revolution, "the total destruction of the 
colonial system" (105) ${ }^{11}$ In the various comments he makes we can discern four reasons for the violence that he observes, or reasons for colonized subjects to exercise violence. First, because the colonized nation was only brought into existence and maintained through violence, to use violence against it is to refuse to pretend, by responding with the language of reason, that the interpretive gesture and interaction initially employed were rational, and, as such, expressive of a sharedness conducive to discourse. The use of violence reveals the fact that the colonized subject has been cut out of the communicative context, unrecognized as capable of reasoned deliberation, and that he is reasonable, not unreasonable, in expecting that communication will be ineffective. ${ }^{12}$ Violence reveals that the original reality of the colonial situation is violence, that the colonizer brought violence "into the homes and minds of the colonized subject" (Wretched 4 , Damnés 42), and that to accept the demands of this reality is not a matter of choice, but a matter of being violently imposed upon by another. Fanon gives the example of Fidel Castro, who attended the meeting of the U.N. in military uniform; what Castro demonstrated in so doing was his awareness "of the continuing regime of violence" (Wretched 38, Damnés 76); he revealed the U.N. as a place of war, not peace.

The second reason for the use of violence is that it aids in the development of unity and hence of the national consciousness required for rehabilitation. It "unifies the people ... [it] is totalizing and national" (Wretched 51, Damnés 90), in that it severs the colonized people from the colonial context in making all paths back to it non-traversable (Wretched 50, Damnés 90). Violence establishes for them a separate and shared ground that becomes available for the production of an indivisible nation of the future, the value of which is not predicated on its usefulness or attachment to the colonist. Fanon expresses this unity and solidarity by saying that in this violence the people are swept up and pitched "in a single direction"; each "represents a 
violent link in the great chain, in the almighty body of violence rearing up in reaction to the primary violence of the colonizer" (Wretched 50, Damnés 90). He gives the example of Kenya's Mau-Mau, an anti-colonial group that advocated violent resistance to British rule in Kenya, each of whom was required to strike the victim such that none could safely return to the colonial situation (Wretched 44, Damnés 82-3).

Third, Fanon implicitly argues that violence restores the self-confidence and agency of the colonized subject, fostering his belief in the possibility that he can create value in the absolute absence of the creator of value, the colonizer-with all ties cut, his agency is still operative. ${ }^{13}$ We can discern this reason in the fact that Fanon calls violence "work" and "absolute praxis" (Wretched 44, Damnés 82), involving not simply destruction but creativity and energy. In that work the colonized subject experiences what it means to have an effect on the world, to elaborate in it his own desire, independently of the agency of the colonizer, and thus to see himself in both subjective and objective form.

Finally, what is destroyed through violence is what Fanon calls the Manichaean world of the colonizer (Wretched 6, Damnés 44), a world divided between those construed as capable of making meaning and those construed as incapable. The violent eradication of the colonial situation is the eradication of the heterogeneity of hierarchy, in which the classes divided are considered internally homogeneous, and the establishment of a homogeneity that is premised on the idea that all people can participate in the construction of meaning, reality, objectivity, and communication. Out of the ashes of the Manichaean world, through the violent appropriation of agency that will not be peacefully given, emerges the possibility of a world that is homogeneous in this sense, a world that provides a foundation for a self-propelled heterogenizationdifferences as generated from within, not imposed from without. But this is not an "all," a 
universality, that already exists; the work of the nation has to be undergone for this universality to be attained. Let us now turn to this issue of universality.

\section{Colonization and false universality}

Fanon's critique of colonialism and his mobilization of national consciousness cause him to reject the promises and resources of the West, including its universal political ideals; his national consciousness leads him to an exclusivity that sits uncomfortably with the inclusivity purported by Western liberal ideals such as freedom, equality, and self-determination. In this section I will give an account of the way in which these ideals are problematic, falsely universal, and complicit in the oppression of colonized subjects. I will also introduce, however, an alternative approach to the possibility of universal political ideals, which in the final section will be elaborated on the basis of the terms of Derrida's philosophy.

Defence of so-called universal political ideals often takes the form of showing how they are organized around the goal of fairness, of respecting all persons equally as persons, regardless of specific differences and idiosyncrasies. It takes the form of explaining how such ideals free up human beings to undertake sophisticated human activities, by allowing for the creation and organization of a shared life in which stability and good treatment can be anticipated. Such ideals are often mobilized in the name of challenging unfairness, and they can be powerful in situations such as the colonial one, in which different kinds of people receive different kinds of treatment for characteristics that have come to have the significance and value they have because of the colonial relation and on the basis of the determining power of only one of the parties.

The colonial context, however, also reveals the limits of these ideals. The basic issue is that such ideals have to be fitted into and enacted in particular situations, and various aspects of 
this particularity are denied in the colonial context. They are attached to a very particular kind of socioeconomic system - in this case, that of the political economy of global capitalism - the success of which is due partly to the exploitation of colonized subjects. The freedom heralded by this system is freedom to participate in this system; the avenues of self-determination are sketched out in advance by it; equality means that all can equally mobilize its resources if they have access to them. Universal principles are accompanied by particular contexts that shape what such principles mean, how they should be interpreted, what their content should be, and what the consequences of their exercise will be, although they can be prejudicially held to be immune to corruptibility. ${ }^{14}$ The promise of such ideals is effective as a promise only in the context of an admission and working-through of the roots of violence and subordination that nourished Western "freedom" and the necessity of particular, exclusive contexts for the nourishing of globally open individuals.

What is at issue here is a deeper, more abstract point concerning the mechanics of the operation of principle, one that makes sense of Fanon's simultaneous commitment to and hostility towards universal principles. Every universal ideal must be worked out in a particular place and in a particular life. It cannot remain formal; it is wedded to particular conditions and given content by particular contexts. Freedom and self-determination will take the shape they do depending on the subjects, groups, or nations determining themselves. Such ideals must be limited in order to be fulfilled; they can only operate, that is, if their universality is made specific, if they are exercised in specific ways for singular people.

Thus, universal ideals will look different depending on the context in which they are invoked. In fact, a Westerner may have an easier time denying the contextualized reality of the ideal, by the contingent fact that she may find it easy to live in the mode of self-reliance in 
abstraction from a particular context. The colonized subject, on the other hand, may find it more difficult — it may be more necessary for her to rely on her particular attachments for the ends of agency and, indeed, survival. In the context of this difference, the particularity of context for the colonized subject is de facto more significant than it is for the Westerner.

What does this point entail for the post-colonial situation? The French colonization of Algeria has produced this colonized nation, a nation with particular, not universal, characteristics, needs, and values. To assume that universal values can be indifferently applied to this particular situation is to fail to honour and satisfy these values, since applying them indifferently entails violently concealing the particular conditions of this nation's production and its particular sense of itself. That is, to apply such universal principles indifferently would result in destroying a nation's freedom, equality, and self-determination. Ideals or principles must be realized in a particular time and place, and in response to a particular set of needs and demands, and they must be consciously identified as so doing. They cannot be dissociated from a specific terrain or articulated without reference to it. If they are employed to erase specificity, then their founding commitment has been seriously undermined. Indeed, in such a context they remain specific - that is, attached to the desires and character of the colonizing power-but that specificity is concealed.

One way, therefore, in which the colonizing power advertently or inadvertently provides its own answer to the experience of the colonized subject-erasing that subject's agency by showing that it has answered all questions, possessed all possibilities, and essentially become the glorious fate of the colonized subject - is that it promises universal liberation with "the richness of Western values" (Wretched 8, Damnés 46). First this system becomes wealthy and "autonomous" through its exploitation of the colonized subject, and then it purports to have the 
tools by which she can transcend her own exploitation and the injury that has accompanied it. Even liberated identity is received identity; even freedom can be imposed. The colonized subject cannot be the responsible agent of the ideals she inherits, the self-determining subject whose very possibility is proclaimed by these values; she is a receptacle of value, not an agent of it. ${ }^{15}$ This is the universality offered by the Manichaean system; it is not the universality to which Fanon alludes. ${ }^{16}$

Fanon offers an evocative illustration of the problematic nature of inheriting freedom when he writes, in Black Skin White Masks:

One day, a good white master, who exercised a lot of influence, said to his friends: "Let's be kind to the niggers."

So the white masters grudgingly decided to raise the animal-machine man to the supreme rank of man, although it wasn't easy.

Slavery shall no longer exist on French soil.

The upheaval reached the black man from the outside. The black man was acted upon. Values that were not engendered by his actions, values not resulting from the systolic gush of his blood, whirled around him in a colourful dance. The upheaval did not differentiate the black man ...

As master, the white man told the black man: "You are now free."

But the black man does not know the price of freedom because he has never fought for it.

From time to time he fights for liberty and justice, but it's always for a white liberty and a white justice, in other words, for values secreted by his masters. ${ }^{17}$ (Black Skin 194-5, Peau Noire 178-9)

A particular political context is necessary for elaborating and satisfying the ideals of liberty and justice, for doing justice to the needs and desires of a citizenry, yet these ideals can be wielded in such a way as to violently suppress such particular contexts.

The requirement that there be a specific context for these values and ideals, however, does not entail their rejection. To think that these values and ideals are inappropriate to the struggle for decolonization is to think in the Manichaean terms of the West. Values can "cross the line," so to speak, in light of and in the interest of the future possible eradication of this line. 
But they cannot be invoked in disregard of the situations and subjects through and for which they are enacted. Their embodiment in particular political contexts is necessary, even though these will be partial, incapable of attaining justice for everybody, and only successful in accomplishing justice for some if they do not try to accomplish it for all. This exercise of universality in the context of particularity, where each is in tension with the other, is required by what I have called "genuine" universality_ or universality that is made to reckon with the inevitable particularity of the domains of its enactment - and it is opposed to the false universality of the liberal Western context. To explore further what this means and what it looks like, let us now look at Derrida's Rogues and at what he calls the essentially aporetic structure of democracy (86).

\section{Fanon, Derrida, and the (im)possibility of universality}

Derrida's invocation, in Rogues, of exclusive democracies and a "democracy to come" (see 8) offers another avenue through which to understand the depth of Fanon's insights into the colonial situation and the tension and relationship between universal principles and the particular contexts of their enactment and expression. The basic insight Derrida offers here can be articulated in two parts. First, democracy, and the ideals by which its democratic promises are carried out, must and always does take a particular shape and have a particular content. Democracy is always only realized in particular democracies and in response to the needs of particular people, such that every democracy is different from every other-there is no essential or proper way in which it exists. Every democracy, in order to be made to respond to the people who lend it legitimacy, is bound by a kind of duty of self-delimitation; it must be exclusive and be shaped so as to be able to effectively engage with those whom it has "chosen" to hear, those whom it has "allowed" to participate in democratic self-governance. But every democracy also 
jeopardizes its democratic character if it is exclusive in this way, if it exercises sovereign independence. The basic principle of democracy involves a commitment to the principle of human self-governance, whatever shape that governance may take, and whatever human beings may enact it. Hence Derrida's second point: in addition to the necessity of democratic delimitation there is the necessity of democratic unlimitedness or openness; at the heart of democracy lies also an impetus to absolute inclusiveness and universality.

Democracies are fraught with tension, ambivalence, and even contradiction, which is apparent in many ways. They may be mobilized to protect individual singularity with law, which through its indifference to singularity also conceals the significance of singularity. They may be made to aim for justice if they are limited to the goal of justice for some and not all. They must be made passively open to the demands that are made of them, but they must also be made to take shape in response to those demands, and must retain sufficient power so as to be able to respond to them. They are characterized by a commitment to deliberation, but such deliberation must end in order that sovereign, singular decisions may be made, decisions that protect and respond to the process of deliberation. The ideal of democracy is ambivalent in these ways and more; it is always under challenge and question. When an answer to the question of how to put into practice democratic ideals is formulated, which must happen, democratic practice and procedure is put to an end, and the possibility of different answers to this question is closed off. Thus Derrida says that democracy

will never exist, in the sense of a present existence: not because it will be deferred but because it will always remain aporetic in its structure (force without force, incalculable singularity and calculable equality, commensurability and incommensurability, heteronomy and autonomy, indivisible sovereignty and divisible or shared sovereignty, an empty name, a despairing messianicity or a messianicity in despair, and so on). (Rogues 86) 
Derrida calls this tension - this insurmountably self-undermining nature-autoimmunity. ${ }^{18}$ In each of its attempts to give itself shape, to respond to the demands of its nature, a democracy puts its very nature to the test. Any specific attempt to be democratic threatens the very existence of democracy.

Let us look more closely at two particular and related exemplifications of democracy's aporetic structure, which will provide a basis for discussing the tension Fanon identifies between the nation and internationalism: the tensions between inclusion and exclusion, and between sovereignty as indivisible and sovereignty as shared, divisible, or unconditional. On the one hand, a democracy must be exclusive and sovereign: it must exclude outsiders in order to be able to respond to the needs of a people, and it must at times exclude the minority within the democracy, in the interest of having a framework and policies take shape around the will of "the people."19 A sovereign decision must be made in order that these needs be satisfied, and democratic deliberation must thereby be closed off. On the other hand, however, democracy is also committed, "in the name of universal equality," to representing "the weakness of the weak, minors, minorities, the poor, and all those throughout the world who call out in suffering for a legitimately infinite extension of what are called human rights" (Rogues 36). Its power, sovereignty, and exclusive identity must be laid down at the feet of the powerless, in an act that testifies to its very motivating principle: the concern for inclusion and universal selfdetermination; indeed, the very purpose of exclusiveness and sovereignty is to empower responsiveness, to sustain the ability to respond to the immigrant, the refugee, the homeless, the needy. Whereas sovereignty concerns the kratos of democracy —its unified, singular poweropenness to otherness favours the "anyone or whoever" (Rogues 58), the "first to happen by" (Rogues 86), the demos of democracy; indeed, the word itself is ambivalent or in tension with 
itself. Democratic self-determination requires what seems to be non-democratic, non-universal exclusion. Democratic justice also requires what seems to be non-democratic injustice; democratic freedom requires what seems to be non-democratic constraint. All of these apparently non-democratic aspects-exclusion, injustice, constraint—are necessary for the existence of actual democracies. Exclusion and indivisible sovereignty exist for the sake of and in the name of inclusion and shared sovereignty, and vice versa. ${ }^{20}$

Hence the dual meaning of Derrida's use of the term de-limit. On the one hand, a democracy must be delimited in the sense of limiting itself, in order to respond to the articulation of particular need "in the name of the singular urgency of a here and now" (Rogues 38). On the other hand, however, this de-limitation is a questioning of limits, a removal of limits, an openness to becoming different. In Rogues, Derrida cites his own Politics of Friendship, naming both aspects of this delimitation: there exists "the possibility and the duty for democracy itself to de-limit itself ... Delimitation not only in the name of a regulative Idea and an indefinite perfectibility but every time in the singular urgency of a here and now" (Rogues 90; Politics 105). The concept of democracy as inclusion runs counter to particular exclusive democracies and is irreducible to them, but each is impossible except in the terms of the other: to be inclusive a democracy has to take actual, limited, exclusive form. To be responsive to the human being who is its priority, a democracy must be something, it must resolutely and sovereignly decide, closing itself off to further determination; but to be responsive to the human being who could always be different and decide differently, it must also be open, refusing to take on content, to be determined. Only as sovereign and self-determining can a democracy adequately respond to its heterogeneous others. But for it to be responsive is for it to suspend sovereignty and self- 
determination for the sake of those to whom it responds. Derrida says that democracy "is what it $i s$ " or is "equal and proper to itself only insofar as it is inadequate and improper" (Rogues 38).

In this context, the meaning of the term democracy-to-come becomes clear. Derrida says that historicity is intrinsic to democracy (Rogues 72), that it is characterized by an "essential delay ... the interminable adjournment of the present of democracy" (Rogues 38). Democracy is never achieved or attained, and, indeed, only in being unachieved and unattained —only in continuing to give itself shape in time- is it democratic. The idea of democracy-to-come points not to any actual future coming of democracy, but to the fact that any actualization of democracy is never sufficient to democracy and must be open to the need to reshape itself in response to what will still appear, open to being shaped by the future participants in its construction. In order to be democracy it must in principle be open to its own transformation, to the possibility that the future will show it its inadequacies, and it is thus open to the possibility of revolution or reform - the possibility that the idea of democracy might demand that it change. It can never abandon this promise and close down the possibility of transformation, which means that it can never be considered achieved, adequate, or fulfilled. There will always be democracy-to-come. In this, indeed, is found a kind of solution to the tension between determinacy and indeterminacy; upon delimitation in the name of responsiveness to the demands of selfgovernance, this delimitation must be recognized as a restriction of the character of democracy, which is also to be infinitely open, or to be unlimited. A democracy must take up its limits as an issue, question, or problem - it must de-limit itself in the sense of becoming limited, but also in the sense of questioning, challenging, revising, and sometimes removing its limits. This is the practice and labour of democracy. 
With the help of Derrida's framework we can shed new light on Fanon's conflicting commitments: the one to the nation, which is irreducibly different from, exclusive of, and even disregarding of others, and the other to the hope for a unified human reality, a reality of universal respect and concern, in which all are considered to have the capacity to make meaning, and all have that capacity concretely sustained. As in Derrida, this conflict is not a problem per se, but Fanon's answer to the problem of colonization. That is, to be concerned with humanity as such, with freedom, with universal equality, and with "whoever arrives" (Rogues 92), we must be wedded to particular, exclusive contexts and enact a particular people - in Fanon's words, the nation. In order to be capable of receiving whoever arrives, we have to have at our disposal the conditions and resources for hospitality, a certain kind of sovereignty over the place of arrival. In order to be ourselves capable of being commanded by whoever arrives, we must ourselves be masters. ${ }^{21}$ Fanon's goal is to eradicate the hierarchical, Manichaean division between the haves and the have nots, the creators and the recipients of meaning, and that requires the mobilization of an exclusively and sovereignly constituted people. His project is to undo the damage done by division and partiality, which is a project essentially performed in the name of universal inclusion and cooperation, but that project itself requires division. In order to reintroduce "man in his totality" (Wretched 62, Damnés 107) and "strengthen man's totality" (Wretched 236, Damnés 302), he says that we must mobilize the nation. Thus is his national consciousness not a full-fledged dedication to one part of humanity over another - it is, rather, energized by the idea of a future reality in which none would be excluded, not even the ex-colonizer, from the capacity to create meaning and value. In other words, he speaks for humanity by opposing it, he speaks against insularity by being insular, against exclusion by excluding. 
Fanon, unlike Derrida, does not reflect upon the possibly necessary and constitutive status of this tension between nationalism and internationalism, but to introduce Derrida's insight into the constitutive nature of this tension-and thus the unachievable nature of a pure universality, democracy, or internationalism-is, I believe, to capture what is at the heart of Fanon's thinking. The idea of a future universality, internationalism, or universal democracy is, to borrow a term from Derrida, im-possible. ${ }^{22}$ On the one hand, it is not a part of individual human capacity, because it involves the inclusion of others and particular human beings could never dictate the terms by which others will be included. On the other hand, however, this idea also makes itself real, in a sense, in our desire, and in the particular things we do in finite contexts; it is present in its effects and its impact on practice, or it is made real in the way that we respond to the "singular urgency of the here and now" (Rogues 90; Politics of Friendship 105); it is the hidden inspiration behind actuality. Thus, while universality, internationalism, or perfect democracy will never come, they are in a sense here or present in the particular actions we undertake in the present for the sake of responsiveness and inclusion.

Both Fanon and Derrida express a commitment to genuine universality in their use of futural language to talk about action and responsibility in the present. Such language must always be futural, for the sake of democracy: it reflects a concern for justice in that it reflects the refusal to delineate characteristics of humanity that would serve to include some and exclude others, and in that to rely on it is to acknowledge the fact that the point of view of the present has been damaged by the appropriation, on the part of some, of the capacity to make meaning for all. Further, Fanon invokes a "new type of man" (Wretched 174, Damnés 229), appropriate to a new kind of world: "If we want humanity to take one step forward ... then we must innovate, we must be pioneers ... make a new start, develop a new way of thinking, and endeavour to create a 
new man" (Wretched 239, Damnés 305). He even requests, in the spirit of inclusiveness, the shared agency of Western "others": to help rehabilitate humanity and ensure its triumph everywhere, once and for all (Wretched 61-2, Damnés 103). Let us endeavour, Fanon says, "to invent a man in full, something Europe has been incapable of achieving" (Wretched 236, Damnés 302). He holds the nation accountable to this propulsion, whereby it would always have to view its own particularity as ambivalent.

Decolonization and the destruction of the Manichaean world will bring forth new human beings, but we cannot speak authoritatively from the point of view of that future - we can only anticipate its possibility, and critically employ, in order to do so, mechanisms that also are oriented toward that possibility, or that are intrinsically characterized by an openness to this future; one such mechanism could be that of democracy. The removal of the Manichaean division will establish the ground for a future sharedness - a new humanism, internationalism, universalism - but this sharedness-to-come is not here now, and thus we see it only as through a glass darkly. The creative "madness" required by any revolution, which in principle cannot be conceived in and through existent terms, is also required here-always before the universality to come has come.

The tension between the indissociable elements of universality and particularity, of open passivity and closed sovereignty, of inclusion and exclusion, keeps the nation a nation of the future, a democracy-to-come. It keeps democracy in front of us as a task that requires labour and persistence; it keeps alive the possibility of meaningful action and responsibility in the present. It keeps alive, and keeps us alive to, the significance of continuing deliberation and discernment with regard to identification of the demos, and responsiveness to its demands. It brings to bear upon us the weight of political and social responsibility, the weight of decision. The idea that 
every response is both an opening and a closing down of possibility renders deliberation significant, decision weighty, and action serious. ${ }^{23}$

The democratic, post-colonial nation, for both Fanon and Derrida, would be mobilized by the values of dignity, justice, and solidarity, and would exist as a concrete and particular site for the satisfaction of universal principles. It would aspire to satisfy those principles, and it would aspire to live in tension with itself as an inadequate vehicle of them, or to live in the practice of self-critique, conscious of its persistent failure, in its particularity, to be faithful to its motivating principles, but also conscious of the significance of its particularity as the only vehicle available for the elaboration of democratic principles. Fanon does this aspiration and this self-critical moment justice when he refuses to say what the post-colonial nation is, preferring instead to observe it come into its own through struggle, and to mobilize its energies by reference to a shared future. In so doing, he carefully closes the door to a Manichaean order and opens a door to an im-possible, futural, and universal internationalism.

\section{Notes}

${ }^{1}$ Colonization thus construed names that we typically understand as such, involving specific peoples and their particular forms of organization, but it could also be metaphorically extended to other forms of domination. I leave the definition broad for the purpose of highlighting the commonalities between such problems, but wish to address mostly the typical understanding in this essay.

${ }^{2}$ Citations will be taken from the following texts: Frantz Fanon, Black Skin, White Masks, tr. Richard Philcox (New York: Grove Press, 2008); Frantz Fanon, Peau noire, masques blancs (Paris: Éditions du Seuil, 1952). It is not insignificant that Fanon neglects to address the place of women in the scenarios of colonization and decolonization, but I will use the pronouns and terms that he uses when explicitly discussing his work, so as to keep his exclusive use of the masculine visible. While I cannot tease out the significance of this exclusion here, I will mention briefly 
Anne McClintock's argument that all nationalisms are gendered, and that where nationalism is present, there feminism has not been "allowed to be more than a maidservant to [it]" (122). She points to the importance of caution with regard to the capacity of national consciousness to erase other significant differences within so as to mobilize all members toward the project of forming and enacting a collective will. Fanon's ambivalent and dynamic approach to nationalism is important in this context; indeed, McClintock identifies him as an exception (105). See also note 8. Thanks are due to an anonymous reviewer for calling my attention to the important points reflected in this essay, as well as in several others.

3 Fanon is referring to an advertisement for "Banania," a French breakfast cereal, which portrayed a grinning Senegalese soldier saying " $Y$ a bon Banania!" " $Y$ a bon" is so-called "African French" for "C'est bon" (See Gordon, 17).

${ }^{4}$ While "The Fact of Blackness," the first published translation of this chapter's title, is a poor choice as a translation, it resonates with Fanon's point here: while blackness is not a fact but produced in the encounter with the white colonial subject, it becomes a fact imposed upon a being that merely is. Lou Turner argues that: "Race is viewed by Fanon in the manner of ancient tragedy, that is, as a fateful condition that weighs upon black lived experience in the sense in which inevitability attaches to all of one's actions. Black lived experience is robbed of its free will ..."(157).

5 In "Alienation and Its Double," Kelly Oliver states that "Fanon's analysis suggests that whereas white culture values individuality and the merits associated with this individualism, oppression works through denying individuality to the oppressed by stereotyping them. The racialized other is seen as always and only a representative of a group, while the race 'neutral' or 'normal' dominant white is seen as an individual whose merit is self-determined" (189).

${ }^{6}$ We should be careful to note what inflection the idea of nation has for Fanon, and Benedict Anderson's Imagined Communities is helpful here for highlighting four different configurations of the nation. The "new American states of the late eighteenth and early nineteenth centuries" first developed conceptions of "nation-ness" (Anderson, 47); these nations were formed by "creoles": that is, by people "of (at least theoretically) pure European descent but born in the Americas" (Anderson, 47, n. 1). These nations defined themselves in opposition to European power, and hence inspired the emergence of the second form, European nations. Third were official nations, reactionary dynasties that invoked nationhood in order to avoid being marginalized by popular national movements in Europe in and after the 1820s (Anderson, 86). Anderson's fourth kind of nation - of which Fanon's Algeria might be an example - was the one associated with colonized countries, where "natives" inducted into colonial systems came to see themselves as nationals and to resist colonization by invoking national consciousness. While helpful, however, Anderson's view of the fourth kind of nation may illicitly attach Algerian identity, for instance, too much to the event of colonization. See Thomas King's "Godzilla vs. Post-Colonial" for a critique of the way in which the very term post-colonial is problematically 
attached to a continuum that presupposes the centrality and pivot-like character of European colonialism.

${ }^{7}$ David Hanley describes Fanon's challenge as that of not only "bringing his nation (Algeria) into existence but of trying to see what the structures of that nation might be" (124). "The nation dominates Fanon's thought, but never as an end in itself; it is always a means, a stimulus, a question-mark" (131).

8 Anne McClintock expresses a favourable view of Fanon's attitude toward nationalism. In her view, he warns "against the pitfalls of national consciousness" (122), aware of the "attendant risks of concealing, and thereby exacerbating, the very real contradictions within the strategic collectivity of nationalism - conflicts of class, gender, ethnicity, regional and generational difference" (123), but he also believes that nationalism "gives vital expression to a popular memory of shared suffering and shared refusal" (122-3). McClintock's own reservations come from what she calls the "gendered character" of nationalisms, and the tendency for them to figure women, for instance, "as mere scenic backdrops to the big-brass business of masculine armies and uprisings," failing to grant women and men "the same privileged access to the resources of the nation-state" (105).

${ }^{9}$ Messay Kebede says that, according to Fanon, the rehabilitation of the past is completely irrelevant "to the concrete demands of the struggle ... Those African scholars who assure that precolonial Africa had known brilliant and advanced forms of civilization do not indicate to what extent this discovery is relevant to liberate Africa from its present misery and subjugation. The memory of a glorious past has no power over present disabilities" (543). This point may be put too strongly, however, and we can turn to Thomas King again for a powerful articulation of a counter-point: the idea that to construe all activity after the event of colonization as somehow defined by it is to cut us "off from our traditions, traditions that were in place before colonialism every became a question, traditions which have come down to us through our cultures in spite of colonization," and to construe "contemporary Native writing [as] largely a construct of oppression" (185).

${ }^{10}$ With the words "while the iron is hot" Sartre is probably making reference, as Fanon does, to "The Internationale" ( see note 1).

11 A prominent critique of Fanon's reliance on violence is found in Hannah Arendt's On Violence. A thoughtful, penetrating, and non-reactionary critique of Fanon's account of violence is found in Anna Carastathis' "Fanon on Turtle Island." While favourable toward certain aspects of Fanon's account of violence, Carastathis: a) uses Taiaiake Alfred's argument that "if Onkwehonwe (original people) are to 'become warriors again,' in the sense that authentically emerges from their cultural, political, and spiritual traditions, this self-transformation must be based on action, not reaction"-or that violence in action is counter-violence ... [and hence] reactive," and what is needed is action (89); b) argues that violence may not have "the capacity to target the real sources of colonial oppression, which on Fanon's account are of a political 
economic order" (89); c) questions whether his account "pays adequate attention to the gendered dynamics of violence in the colonial situation" (91-2); and d) wonders whether through it can be produced the tools for the construction of a "society beyond violence" (92). Without exploring these arguments in detail, I will simply elaborate Fanon's justification for violence on its own terms, for several reasons. To begin, to assess such claims from outside of the colonial context is to risk overlooking the fact that one is caught up in or complicit with the violence of colonialism. Fanon, speaking from within the colonial situation, perceives real and profound reasons for violence that are felt and acted on from within that situation, and my goal is to try to bring that situation to life in some way. Further, it is in fact unclear whether his discussion of violence prescribes it, or whether he is merely observing and describing a violence that is already happening and explaining why it is happening. According to Ato Sekyi-Otu, for instance, Fanon's analysis of violence should be understood as a "dramatic dialectical narrative" instead of "a doctrinal prescription" (4). Finally, my ultimate goal is to explore how a (violent or nonviolent) self-separation can still be the basis of a certain kind of human universality, and so I will orient my argument toward this goal.

12 Olipado Fashina argues that because "colonial economic structure is established by and is sustained through violence" (198), there is no real reason "to believe that moral persuasion and moral arguments alone could bring about the new social structure ... Appeal to common interests is not ... enough ... since both parties in the conflict believe that there is no communality of interests" (199). Fashina argues, further, that "to bring about a world more just, more egalitarian, more democratic, we ought to change colonial social structure ... [so] violent overthrow of colonial rule is justified" (201). Carastathis would probably challenge this last association, since being able to bring about a world seems dependent on being capable not just of destructive reaction but creative action, which practice in violence may not effectively cultivate. See note 11.

13 Sartre says that Fanon "shows perfectly clearly that this irrepressible violence is neither a storm in a teacup nor the reemergence of savage instincts nor even a consequence of resentment: it is man reconstructing himself' (Preface to Wretched lv, Damnés 28-9).

${ }^{14}$ Indeed, the contact the colonized subject has with the forces of universalization often occurs in situations of constraint. For instance, countries can receive loans from Western agencies such as the International Monetary Fund on condition that they revise their national social services; underprivileged individuals participate in the globalization of the economy by working for Western factories in low-paying jobs, by performing migrant labour, by being trafficked, etc. (see Rao, "Postcolonial Cosmopolitanism" 7). The trend towards a global economy affects different players in radically divergent ways.

${ }^{15}$ As Neil Roberts writes, "decolonization requires the colonized to take, rather than accept, the condition of freedom" (144). 
${ }^{16}$ Sartre says that "we must confront an unexpected sight: the striptease of our humanism. Not a pretty sight in its nakedness: nothing but a dishonest ideology, an exquisite justification for plundering; its tokens of sympathy and affectation, alibis for our acts of aggression" (Preface to Wretched lviii, Damnés 31).

${ }^{17}$ Benedict Anderson cites a nice example of the white ownership of freedom when he describes the Dutch colonial regime's 1913 colony-wide festivities celebrating the national liberation of the Netherlands from French imperialism. The subject native population was expected to celebrate Dutch freedom through physical participation in the festivities and financial contributions to it (see 116-7).

${ }^{18}$ Michael Naas says that democracy is autoimmune because its concept undecidable; it is "essentially void of any content or meaning in and of itself... it is thus always open to iteration and reinscription, its meaning in some sense always still to come" (Naas 133).

${ }^{19}$ Naas says that "whenever it is practiced, democracy, in the name of democracy, in the name of its own protection and immunization, always excludes some of the demos from its practices, whether this be in the right to securing citizenship, in voting, or in serving in government, and it always, again in the name of protecting democracy, defers or adjourns democracy 'itself' to another day" (136).

${ }^{20}$ As Leonard Lawlor notes, the "universal movement" of globalatinization "erodes the borders between nation-states," and, while this may seem inclusive and thus more appropriate to democracy, it "increases the probability of the worst happening" (39).

${ }^{21}$ Here I am borrowing the language and conceptual framework of Derrida's "Of Hospitality." According to this framework, we can see why it makes sense that the colonizers may be forced to leave, even given the imperative to be open to "whoever arrives," for one cannot sustain the conditions of hospitality in the face of those who would destroy them.

${ }^{22}$ See, for instance, Derrida's "To Forgive: The Unforgivable and the Imprescriptible," in John D. Caputo, Mark Dooley, and Michael J. Scanlon, eds., Questioning God (Bloomington, IN: Indiana University Press, 2001), 29.

${ }^{23}$ In Third World Protest, Rahul Rao argues that "a combination of cosmopolitan and communitarian sensibilities is most appropriate to the condition of post-coloniality" (199), and that it is urgent and necessary to combine "cosmopolitan and communitarian sensibilities" (200). He calls attention to the need for judgement, illuminating situations in which one would be preferable over the other, and vice versa: for instance, situations in which universal, cosmopolitan principles are appealed to in attempts to democratize unjust states, and, alternatively, situations in which "the nationalist discourse of protest movements aims at a 'renationalization"" of states that have "prioritized their responsibilities to global capital ... over their commitment to ensuring the socio-economic needs of their own citizens" (170-1). 


\section{Works Cited}

Alfred, Taiaiake. Wasáse: Indigenous Pathways of Action and Freedom. Peterborough, ON: Broadview Press, 2005.

Anderson, Benedict. Imagined Communities. New York: Verso, 1983.

Arendt, Hannah. On Violence. New York: Harcourt, Brace and World, 1970.

Carasthatis, Anna. "Fanon on Turtle Island: Revisiting the Question of Violence." Fanon and the Decolonization of Philosophy. Ed. Elizabeth Hoppe and Tracey Nicholls. Lanham, MD: Lexington Books, 2010. 77-102.

Chari, Anita. "Exceeding Recognition." Sartre Studies International 10 no. 2 (2004): 110-22.

Derrida, Jacques. Of Hospitality. Trans. Rachel Bowlby. Stanford: Stanford University Press, 2000.

-. Rogues: Two Essays on Reason. Trans. Pascale-Anne Brault and Michael Naas. Stanford: Stanford University Press, 2005.

—. The Politics of Friendship. Trans. George Collins. London: Verso, 2005.

-. "To Forgive: The Unforgivable and the Imprescriptible." Questioning God. Ed. John D. Caputo, Mark Dooley, and Michael J. Scanlon. Bloomington, IN: Indiana University Press, 2001. 21-51.

Fanon, Frantz. A Dying Colonialism. Trans. Haakon Chevalier. New York: Grove/Atlantic, Inc., 1965.

—. Black Skin, White Masks. Trans. Charles Lam Markmann. New York: Grove Press, 1967.

—. Les damnés de la terre. Paris: Éditions La Découverte \& Syros, 2002.

—.Peau noire, masques blancs. Paris: Éditions du Seuil, 1952.

—. Toward the African Revolution. Trans. Haakon Chevalier. New York: Grove Press, 1967.

—. The Wretched of the Earth. Trans. Richard Philcox. New York: Grove Press, 1963.

Fashina, Olipado. "Frantz Fanon and the Ethical Justification of Anti-Colonial Violence." Social Theory and Practice 15 no. 2 (Summer 1989): 179-212. 
Gandhi, Leela. Postcolonial Theory: A Critical Introduction. New York: Columbia University Press, 1998.

Gordon, Lewis. "Through the Zone of Nonbeing: A Reading of Black Skin, White Masks in Celebration of Fanon's Eightieth Birthday." The C. L. R. James Journal 11 no. 1 (Summer 2005): 1-43.

Hanley, David. "Frantz Fanon-Revolutionary Nationalist?" Political Studies 24 no. 2 (June 1976): 120-31.

Kebede, Messay. "The Rehabilitation of Violence and the Violence of Rehabilitation: Fanon and Colonialism.” Journal of Black Studies 31 no. 5 (May 2001): 539-62.

King, Thomas. "Godzilla vs. the Post-colonial." World Literature Written in English 30 no. 2 (1990): 10-16.

Lawlor, Leonard. This is Not Sufficient. New York: Columbia University Press, 2007.

Marx, Karl. "On the Jewish Question." The Marx-Engels Reader, $2^{\text {nd }}$ ed. Ed. Robert C. Tucker. New York: W. W. Norton and Company, 1978.

McClintock, Anne. "No Longer in a Future Heaven: Nationalism, Gender and Race." Transition 51 (1991): 104-23.

Naas, Michael. Derrida From Now On. New York: Fordham University Press, 2008.

Oliver, Kelly. "Alienation and Its Double; or, The Secretion of Race." Race and Racism in Continental Philosophy. Ed. Robert Bernasconi and Sybol Cook. Bloomington, IN: Indiana University Press, 2003. 176-95.

- The Colonization of Psychic Space: A Psychoanalytic Social Theory of Oppression. Minneapolis: University of Minnesota Press, 2004.

Rao, Rahul. "Postcolonial Cosmopolitanism: Making Place for Nationalism." European Standing Group on International Relations, Stockholm, Sweden, September 2010. Web 1 Jan. 2012.

—. Third World Protest: Between Home and the World. Oxford: Oxford University Press, 2010.

Roberts, Neil. "Fanon, Sartre, Violence, and Freedom." Sartre Studies International 10 no. 2 (2004): 139-60.

Sartre, Jean-Paul. Preface. Wretched of the Earth. By Frantz Fanon. Trans. Richard Philcox. New York: Grove Press, 1963. 
Sekyi-Otu, Ato. Fanon's Dialectic of Experience. Cambridge, MA: Harvard University Press, 1996.

Turner, Lou. "Fanon Reading (W)right, the (W)right Reading of Fanon: Race, Modernity, and the Fate of Humanism." Race and Racism in Continental Philosophy. Ed. Robert Bernasconi and Sybol Cook. Bloomington, IN: Indiana University Press, 2003. 151-75. 